\title{
C677T Methylenetetrahydrofolate Reductase (MTHFR) Gene Polymorphism and Treatment Response in Schizophrenia Patients
}

\author{
Muthmainah Muthmainah ${ }^{1^{*}}$, Nova Kurniasari ${ }^{2}$, Mohammad Fanani ${ }^{2}$, Debree \\ Septiawan $^{2}$, and Adriesti Herdaetha ${ }^{2}$ \\ ${ }^{I}$ Faculty of Medicine Universitas Sebelas Maret Surakarta, Indonesia \\ Jalan Ir.Sutami No.36A, Kota Surakarta, Jawa Tengah 57126 \\ ${ }^{2}$ Department of Psychiatry Faculty of Medicine Universitas Sebelas Maret Surakarta, Indonesia \\ Jalan Ir.Sutami No.36A, Kota Surakarta, Jawa Tengah 57126 \\ *Corresponding author: muthmainah.fkuns@gmail.com
}

\begin{abstract}
Background: Schizophrenia is one of the most common psychiatric disorders. Antipsychotics are widely used to treat schizophrenia. However, around $20 \%$ of people with schizophrenia fail to respond to antipsychotic treatment. Treatment response is influenced by genetic factor. Polymorphism of APOE, NOTCH4 and COMT gene has been reported to be associated with treatment resistance in schizophrenia. Other gene such as MTHFR gene is considered to be involved in the development and prognosis of schizophrenia. Currently, studies that investigate the association between MTHFR gene polymorphism and treatment response in schizophrenia is very rare, especially in Indonesia. Objective: To examine the association between C677T MTHFR gene polymorphism and therapeutic response in patients with schizophrenia in dr. Zainudin Arif hospital, Surakarta. Method: A total of 60 schizophrenia patients of whom 30 were resistant to treatment and 30 were responsive, took part in the study. Peripheral blood was drawn from the subjects for DNA extraction. MTHFR gene polymorphism was determined with ASO PCR method. Result: There is no significant difference between polymorphism status and treatment response $(p=0.085)$. Additional analysis revealed that relapse rate significantly influenced treatment response $(p=0.001)$. Conclusion: C667T MTHFR gene polymorphism is not associated with treatment response in schizophrenia.
\end{abstract}

Keywords: Treatment Response, MTHFR, Polymorphism, Schizophrenia

\section{INTRODUCTION}

Schizophrenia is one of the most common psychiatric disorders. The core clinical manifestations of schizophrenia include delusions, hallucinations, disorganized thinking, abnormal motor behavior and negative symptoms (American Psychiatric Association, 2013). In many cases, the course of the disease tends to be chronic and recurrent requiring life-long treatment. It is reported that the prevalence of schizophrenia is around $1 \%-3 \%$ worldwide (Eaton, Chen, \& Bromet, 2011).

Antipsychotics have been widely used to treat schizophrenia. However, around $20 \%$ of people with schizophrenia fail to respond to antipsychotic treatment. This proportion remains unchanged from time to time. Therefore, therapeutic management of patients resistant to pharmacological treatment still becomes an important health problem that need to be addressed (Caspi, 2004).

Treatment response is influenced by genetic factor. Several studies have investigated the influence of genetic factors on response to antipsychotic treatment. Durany et al (2000) 
reported that polymorphism of $A P O E$ gene was associated with poor response to antipsychotic while Antila (2004) revealed that combination of NOTCH4 and COMT gene polymorphism resulted in treatment resistance in schizophrenia (Anttila, et al, 2004). Other gene such as MTHFR gene is considered to be involved in the development and prognosis of schizophrenia. MTHFR gene encodes an enzyme called methylenetetrahydrofolate reductase which is responsible to catalyze the conversion of 5,10-methylenetetrahydrofolate into the active form of folic acid, 5-methyltetrahydrofolate. This active form is a co-substrate required to convert homocystein into metionin. Metionin is crucial for DNA methylation and plays a role in gene transcription, replication, and DNA repair (Crider, et al, 2012). MTHFR gene polymorphism have been reported to be associated with schizophrenia in several ethnics such as Caucasian, Hispanic, Australian and Asian (Gilbody et al 2007 and Arzaghi et al 2011). C677T MTHFR gene polymorphism was associated with increased the risk of developing schizophrenia (El-Hadidy et al, 2014)

Currently, studies that investigate the association between MTHFR gene polymorphism and treatment response in schizophrenia is very rare, especially in Indonesia. Joober et al (2000) have indicated different distribution of MTHFR gene polymorphism in responsive and non-responsive schizophrenia patients (Joober et al, 2000). However, further investigations are needed to clarify the relationship between this gene polymorphism and treatment resistance in schizophrenia. This study aimed to examine the association between C677T MTHFR gene polymorphism and therapeutic response in patients with schizophrenia in dr. Zainudin Arif hospital, Surakarta.

\section{METHOD}

This was an analytic observational study with cross sectional design. A total of 60 schizophrenia patients of whom 30 were resistant to treatment and 30 were responsive, took part in the study. Patients who met Diagnostic and Statistical Manual of Mental Disorders V (DSM-V) or Pedoman Penggolongan Diagnosis Gangguan Jiwa (PPDGJ) criteria for schizophrenia were recruited from dr. Arif Zainudin Hospital in Surakarta. Subjects were included in the study if they have been diagnosed with schizophrenia for at least 2 years. Those with history of drug and alcohol abuse, pregnancy, epilepsy, mental retardation, other organic abnormalities and severe diseases were excluded. Treatment response was defined according to previous study by Fanani (2013). Subjects were classified as resistant to treatment when significant clinical improvement was not achieved after adequate treatment with antipsychotic for two weeks as shown by PANSS score. Subjects with a score of at least 4 in one of the the positive scale items of PANSS criteria were regarded as resistant to treatment. Prior to the study, informed consent form were signed by all participants. Peripheral blood was drawn from the subjects for DNA extraction. MTHFR gene polymorphism was determined with ASO PCR method followed by direct sequencing for confirmation. Data were analyzed using Chi Square test with SPSS for WindowsRelease 22.0 The significance level was set at $\mathrm{P}<0.05$.

\section{RESULT AND DISCUSSION}

This study aimed to investigate the association between C677T MTHFR gene polymorphism and treatment response in schizophrenia patients in dr. Arif Zainuddin Hospital in Surakarta, Indonesia. A total of 60 schizophrenia patients were enrolled in this study. Among these participants, 30 patients were classified as responsive to treatment while the other 30 patients were non-responsive to treatment. Subject characteristics are described in Table 1. 
Table 1 Subject Characteristics

\begin{tabular}{|c|c|c|c|c|}
\hline Characteristic & $\begin{array}{l}\text { Treatment- } \\
\text { Responsive }\end{array}$ & $\begin{array}{l}\text { Treatment- } \\
\text { Resistant }\end{array}$ & Total $(\mathrm{n}=60)$ & P value \\
\hline Gender & & & & 0.603 \\
\hline Male & $14(46.67 \%)$ & $14(46.67 \%)$ & $28(46.67 \%)$ & \\
\hline Female & $16(53.33 \%)$ & $16(53.33 \%)$ & $32(53.33 \%)$ & \\
\hline Age (year) & & & & 0.816 \\
\hline$<\mathbf{2 0}$ & $0(0 \%)$ & $1(3.33 \%)$ & $1(1.67 \%)$ & \\
\hline 20-30 & $6(20 \%)$ & $5(16.67 \%)$ & $11(18.33 \%)$ & \\
\hline $31-40$ & $15(50 \%)$ & $13(43,33 \%)$ & $28(46.67 \%)$ & \\
\hline $41-50$ & $8(26.67 \%)$ & $9(30 \%)$ & $17(28.33 \%)$ & \\
\hline $51-60$ & $1(3.33 \%)$ & $2(6.67 \%)$ & $3(5 \%)$ & \\
\hline Age of onset (year) & & & & 0.070 \\
\hline $15-35$ & $19(63.33 \%))$ & $26(86.66 \%)$ & $45(75 \%)$ & \\
\hline$>35$ & $11(36.67 \%)$ & $4(13.33 \%)$ & $15(25 \%)$ & \\
\hline $\begin{array}{l}\text { Recurrence Rate } \\
\text { (per year) }\end{array}$ & & & & 0.001 \\
\hline $0-1$ & $29(96.67 \%)$ & $17(56.67 \%)$ & $46(76.67 \%)$ & \\
\hline$>1$ & $1(3.33 \%)$ & $13(43.33 \%)$ & $14(23.33 \%)$ & \\
\hline
\end{tabular}

Our study revealed that the proportion of C677T MTHFR gene polymorphism was relatively high in schizophrenia patients. Table 2 shows the genotype frequency and allele distribution of MTHFR gene in our study. The genotyping results showed that the majority of schizophrenia patients had polymorphism (90\%). All of the polymorphisms were found to be heterozygous (CT) and none of them were homozygous (TT). Overall, the frequency of T allelic C677T MTHFR gene polymorphism is 54\%.

Table 2 Genotype Frequency and Allele Distribution of C677T MTHFR gene Polymorphism in Schizophrenia

\begin{tabular}{cc}
\hline Variable & Frequency n (\%) \\
\hline Allele & $66(55)$ \\
\hline C & $54(45)$ \\
\hline T & \\
\hline Genotype & $6(10)$ \\
CT & $54(90)$ \\
TT & $0(0)$ \\
\hline
\end{tabular}

Until today, there has been no published work reporting the association between C677T MTHFR gene polymorphism and psychiatric disorder in Indonesia, especially schizophrenia. This is the first study that investigates the role of C677T MTHFR gene polymorphism in schizophrenia patients in Surakarta. It is quite surprising to find that the frequency of this polymorphism is relatively high at up to $90 \%$ in our sample. Previous studies in Indonesian population showed that the frequency of C677T MTHFR polymorphism was much lower than our result. Widjajakusumah reported a $17 \% \mathrm{CT}$ genotype and $10 \% \mathrm{~T}$ allele frequency among healthy population in Bandung (Widjajakusumah, 2004). Similarly, Primasari found a $10.6 \% \mathrm{~T}$ allele frequency with $21.2 \% \mathrm{CT}$ and $0 \%$ TT genotype (Primasari, 
2008). In addition, Gamayani et al. revealed that in cerebral palsy patients, the frequency of C677T MTHFR polymorphism was $18 \%$ consisting of $4 \%$ TT and $14 \%$ CT genotype with T allele frequency at $11 \%$ (Gamayani et al, 2016). Our study found that the frequency of $\mathrm{T}$ allele was relatively high at $45 \%$. This is in line with previous report showing that the frequency of $\mathrm{T}$ allele significantly increased among subjects with schizophrenia .

We further analyzed the association between C677T MTHFR gene polymorphism with the treatment response. Results of the association analysis are described in Table 3.

Table 3 Result of Association Analysis between Responsive and Resistant Patients with and without C677T MTHFR gene polymorphism

\begin{tabular}{lccc}
\hline Variable & \multicolumn{2}{c}{ Schizophrenia } & p value \\
\hline & Responsive, n (\%) & Resistant, n (\%) & 0.085 \\
\hline Polymorphism & & & \\
Positive & $25(83.3 \%)$ & $29(96.67 \%)$ & \\
Negative & $5(16.67 \%)$ & $1(3.33 \%)$ & \\
\hline
\end{tabular}

This study showed that the frequency of C677T MTHFR positive polymorphism in schizophrenia patients that were responsive to treatment was $83.3 \%$ while the frequency in non-responsive subjects was $96.67 \%$. Statistic analysis showed that there was no significant association between polymorphism status and treatment response $(\mathrm{p}=0.195)$. In addition, treatment response was also not associated with the age at disease onset $(\mathrm{p}=0.70)$ while the number of relapse significantly influenced response to treatment $(\mathrm{p}=0.001)$.

Several studies have also investigated the association between C677T MTHFR gene polymorphism and schizophrenia, including the association to treatment response. In one meta-analysis, the homozygote variants (TT) were shown to significantly increase the risk of schizophrenia whereas no significant association was found in the heterozygote variants (Gilbody, Lewis, and Lighfoot, 2007).Other study reported that the frequency of $\mathrm{T}$ allele were larger responsive subjects than in non-responsive subjects. The long term outcome were found to be better in subjects with polymorphism (Joober et al, 2000). C to T mutation was also associated with improvement in the positive symptoms of schizophrenia patients as shown by the reduction of clinical global impression (CGI) score (Vehof, 2012). Subjects who showed better treatment response and long term outcome were found to be carrier of MTHFR mis-sense mutation when compared to healthy control or subjects with treatment resistance (Joober et al, 2000). In our study, the frequency of polymorphism in responsive patients was slightly larger than that of the non-responsive patients and no significant association between the polymorphism and treatment response was found.

MTHFR gene encodes an enzyme that plays a role in folate metabolism, neurotransmitter synthesis, regulation of homocystein level and biosynthesis of $\mathrm{S}$ adenosylmethionine (SAM). Theses processes were shown to be disrupted in some psychiatric disorders including depression and schizophrenia (Gilbody, Lewis, and Lighfoot, 2007). MTHFR enzyme is required to convert 5,10-methyilenetetrahydrofolate into 5methylenetetrahydrofolate, the most important form of folate in the circulation. 5methylenetetrahydrofolate provides one methyl group to homocysteine during the biosynthesis of SAM, the main source of methyl groups in the brain (Gilbody, Lewis, and Lighfoot, 2007).

Genetic variance of MTHFR gene as a result of substitution of nucleotide 677 in exon 4 from $\mathrm{C}$ to $\mathrm{T}$ leads to a change in the amino acid formation giving rise to thermolabile enzyme with disrupted function. Homozygous variant of C677T MTHFR gene polymorphism only have $30 \%$ of enzyme activity while the heterozygous variant maintain its activity at $65 \%$ 
as compared to wild-type (Rozen, 1996). Disruption of enzyme function due to MTHFR gene polymorphism will increase homocysteine level ( $\mathrm{Wu}$ et al, 2013). Homocysteine and its metabolite might have a direct excitotoxic effect on $\mathrm{N}$-methyl- $D$-aspartate glutamate (NMDA) receptor and blocks methylation process of biogenic amines such as neurotransmitter and phospholipid in the central nervous system (Bjelland, Ueland, and Vollset, 2003). Through activation of NMDA receptor, increased homocysteine can be neurotoxic to dopaminergic neurons (Seshadri, 2003). In addition, increased homocysteine and reduced SAM can decrease dopamine level because L-dopa cannot be converted efficiently into dopamine (Rozycka, 2013). It has been well known that dopaminergic neuron hyperactivity is associated with the positive symptoms in schizophrenia. Thus, MTHFR polymorphism might have beneficial effect on treatment response in schizophrenia and provides synergistic effect to anti-psychotic drug (Joober et al, 2000). Anti-psychotic drug serves as dopamine receptor antagonist while MTHFR gene polymorphism might reduce dopamine level and blocks dopaminergic neurotransmission (Rozycka, 2013). Therefore, in addition to being the risk factor for schizophrenia, MTHFR might also serve as a predictor of treatment outcome (Joober et al, 2000).

Treatment response is a complex process in which many factors may contribute to the mechanism. In addition to genetic influence, other factors such as dose and duration of antipsychotic therapy can affect treatment response. Inadequate dose and duration can lead treatment resistance. Each antipsychotic has its own therapeutic dose that has to be adjusted with disease phase of the schizophrenia patient. Inappropriate adjustment of anti-psychotic administration during different phase will increase the possibility of treatment resistance. Clinical factor such as disease severity at onset, duration of untreated psychosis and age at onset directly correlates with treatment efficacy (Arranz, Blanco, and Samperiz, 2016). In this study, we found that the relapse rate significantly influence response to treatment. Factors such as adherence to medication and adequacy of drug dose and treatment duration can contribute to the degree of relapse rate in schizophrenia patients (Arranz, Blanco, and Samperiz, 2016). We realized that factors that may contribute to treatment resistance in schizophrenia is way more complex than just genetic factor. The fact that we do not look at other factors such as social and environmental factors, family support, drug interaction, and other confounding factors is one of the limitations of our study. In addition, the number of sample that we used was low. However, this preliminary study revealed that the frequency of C677T MTHFR gene polymorphism among schizophrenia patients in Surakarta is quite high suggesting the importance of genetic factor in the development of the disease. Therefore, further research are needed to investigate the role of MTHFR gene polymorphism in the pathogenesis of schizophrenia.

\section{CONCLUSION}

The frequency of C667T MTHFR gene polymorphism among schizophrenia patients is quite high. However, there is no associated between this polymorphism with treatment response in schizophrenia.

\section{REFERENCES}

American Psychiatric Association, 2013. Diagnostic and Statistical Manual of Mental Disorders, Fifth Edition. Arlington, VA

Anttila, S., A. Illi, O. Kampman, K. M. Mattila, T. Lehtimäki, and E. Leinonen, 2004. Interaction between $\mathrm{NOTCH} 4$ and catechol-O-methyltransferase genotypes in 
schizophrenia patients with poor response to typical neuroleptics. Pharmacogenetics and Genomics, 14(5), 303-307.

Arranz, M. J. , J. P. Blanco, and B. A. Samperiz, 2016. Pharmacogenetics of the efficacy of antpsychotic drugs in scizophrenia in Genetic Influences on Response to Drug Treatment for Major Psychiatric Disorders. edited by Janusz K. Rybakowski, Alessandro. Springer International Publishing. Switzerland. Pp: 1-20

Arzaghi, S. M., A. Hossein-Nezhad, S.V. Shariat, A. Ghodsipour, J. Shams, and B. Larijani, 2011. C677T Methylenetetrahydrofolate reductase (MTHFR) gene polymorphism in schizophrenia and bipolar disorder: an association study in iranian population. Iranian Journal of Psychiatry, 6(1), 1.

Bjelland, I., P. M. Ueland, and S. E. Vollset, 2003. Folate and depression. Psychotherapy and Psychosomatics, 72(2), 59-60.

Caspi, A., 2004. Treatment-refractory schizophrenia. Dialogues Clin Neurosci., 6(1): $61-$ 70

Crider, K. S. , T. P. Yang, R. J. Berry, and L.B. Bailey, 2012. Folate and DNA Methylation: A Review of Molecular Mechanisms and the Evidence for Folate's Role. Adv Nutr, 3: 21-38.

Durany N, P. Riederer and FF Cruz-Sanchez, 2000. Apolipoprotein E genotype in Spanish schizophrenic patients. Psychiatr Genet 10:73-77

Eaton, W. W., C. Y. Chen, and E. J. Bromet, 2011. Epidemiology of schizophrenia. Textbook of Psychiatric Epidemiology, Third Edition, 263-287.

El-Hadidy, M. A., H. M. Abdeen, S. M. Abd El-Aziz, and M. Al-Harrass, 2014. MTHFR gene polymorphism and age of onset of schizophrenia and bipolar disorder. BioMed research international,

Fanani, H. M., 2013. Perbedaan keefektifan antara clozapine (Clorilex) dengan electro convulsive therapy (ECT) dalam penatalaksanaan skizofrenia resisten obat di rumah sakit jiwa daerah surakarta. Jurnal Wacana Psikologi, 5(10).

Gamayani, U., M.H. Machfoed, P. Idjradinata, T.H. Achmad, 2016. Relationship between C677T Metilenetetrahidrofolat Reductase (MTHFR) gene Polymorphism and Homocysteine in cerebral Palsy. IJIHS. 4(1): 20-5

Gilbody, S. , S. Lewis, and T. Lighfoot, 2007. Methylenetetrahydrofolate Reductase (MTHFR) Genetic Polymorphisms and Psychiatric Disorders: A HuGE Review Am. $J$. Epidemiol. 165 (1): 1-13.

Joober R, C. Benkelfat , S. Lal1 , D. Bloom , A. Labelle , S. Lalonde , G. Turecki1 et al., 2000. Association between the methylenetetrahydrofolate reductase $677 \mathrm{C} \rightarrow \mathrm{T}$ missense mutation and schizophrenia, Molecular Psychiatry, 5:323-326.

Primasari, A., 2008. Asosiasi Polimorfisme Gen Metilenetetrahidrofolatreductase dan Gen transforming Growth Factor Alpha serta pengaruh Lingkungan pada Celah Bibir non Sindromik. [Dissertation]. Bandung: Universitas Padjajaran

Rozen, R., 1996. Molecular genetics of methylenetetrahydrofolate reductase deficiency. Journal of Inherited Metabolic Disease, 19(5), 589-594.

Rozycka, A., P.P. Jagodzinski, W. Kozubski, M. Lianeri, and J. Dorszewska, 2013. Homocysteine Level and Mechanisms of Injury in Parkinson's Disease as Related to MTHFR, MTR, and MTHFD1 Genes Polymorphisms and L-Dopa Treatment 3. Current Genomics, 14:534-542

Seshadri, A. Beiser, A. Selhub, J. Jacques, P. F. Rosenberg, I. H. D'Agostino, R. B. ; Wilson, P. W. ; Wolf, P. A., 2002. Plasma homocysteine as a risk factor for dementia and Alzheimer's disease. N. Engl. J. Med. ,346(7): 476-483. 
Vehof J, H. Burger, B. Wilffert, A. Hadithy, B.Z. Alizadeh, H. Snieder, 2012. Clinical response to antipsychotic drug treatment: Association study of polymorphisms in six candidate genes, European Neuropsychopharmacology, 22:625-631

Wu, Y. L., X. X. Ding, Y. H. Sun, H. Y. Yang, J. Chen, X. Zhao, . . . and Z.Q. Wu, 2013. Association between MTHFR C677T polymorphism and depression: An updated metaanalysis of 26 studies. Progress in Neuro-Psychopharmacology and Biological Psychiatry, 46, 78-85.

Widjajakusumah, B., 2004. Peran Mutasi Gen Metilenetetrahidrofolatreductase (MTHFR) $677 \mathrm{C} \rightarrow \mathrm{T}$ kadar homosistein plasma dan kadar folat plasma dalam terjadinya sindrom koroner akut. [Dissertation]. Bandung: Universitas Padjajaran 